\title{
SIMULASI NUMERIK MEKANISME TURBULENSI DEKAT AWAN KONVEKTIF
}

\section{A Numerical Simulation of Turbulence Mechanism Near Convective Cloud}

\author{
Ni Putu Tiana Verayanti'), ( Kadek Nova Arta Kusuma2) \\ 1) Stasiun Meteorologi Sam Ratulangi. JI. A.A Maramis, Bandara Sam Ratulangi Manado \\ Sulawesi Utara 95374. \\ 2) Badan Meteorologi Klimatologi dan Geofisika. Jl. Angkasa 1 No.2, Kec. Kemayoran, Kota Jakarta \\ Pusat, DKI Jakarta 10610. \\ *E-mail: putu.tiana@bmkg.go.id
}

\begin{abstract}
Intisari
Turbulensi yang dialami oleh pesawat komersial rute Jakarta-Medan telah dilaporkan mengalami Clear Air Turbulence (CAT) di atas Sumatera Utara pada tanggal 24 Oktober 2017. Namun berdasarkan data citra satelit Himawari dari Badan Meteorologi, Klimatologi, dan Geofisika (BMKG) Indonesia menyebutkan bahwa di sekitar lokasi turbulensi terdapat awan kumulonimbus. Penelitian ini memanfaatkan model WRF-ARW dengan resolusi spasial dan temporal tinggi untuk mengetahui secara detail proses yang terjadi pada awan konvektif penyebab Near Cloud Turbulence (NCT). Turbulensi tersebut disebabkan oleh bilangan Richardson rendah yang terbentuk di wilayah udara jernih (clear air) yang berjarak 300-700 m di atas puncak awan dan diperkuat dengan adanya Turbulensi Energi Kinetik (TKE) mencapai $4,4 \mathrm{~m}^{2} / \mathrm{s}^{2}$ dan geser angin vertikal (VWS) oleh arus keluar awan konvektif.
\end{abstract}

Kata Kunci: Turbulensi, NCT, TKE, VWS, Richardson Number

\begin{abstract}
Turbulence encountered by commercial aircraft Jakarta-Medan routes has been reported that experienced Clear Air Turbulence (CAT) over North Sumatra on October 24th, 2017. However, based on Himawari satellite imagery data produced by Agency for Meteorology, Climatology, and Geophysics (BMKG), Indonesia stated that there was a cumulonimbus cloud around the turbulence location. This study utilizes WRF-ARW models with a high spatial and temporal resolution to find out in detail the processes that occur in convective clouds causing Near Cloud Turbulence (NCT). The turbulence was caused by a low Richardson number formed in the clear-air area, which has a distance of $300-700 \mathrm{~m}$ above the cloud top and reinforced by the existence of Turbulence Kinetic Energy (TKE) reaching 4,4 m2/s2 and vertical wind shear (VWS) by deep convection's outflow.
\end{abstract}

Keywords: Turbulence, NCT, TKE, VWS, Richardson Number

\section{PENDAHULUAN}

Turbulensi merupakan salah satu fenomena cuaca yang menjadi ancaman bagi dunia penerbangan. Berdasarkan penyebabnya, turbulensi yang dialami pesawat dapat muncul dari tiga sumber utama yaitu ketidakstabilan wind shear vertikal, gelombang gunung, dan aktivitas konvektif (Storer et al., 2019). Awan konvektif dalam (deep convection) cenderung aktif di atas benua tropis dan area di antara pasifik barat dan samudra hindia (COMET, 2011). Oleh karena itu, wilayah Indonesia berpotensi tinggi mengalami turbulensi diakibatkan oleh aktivitas awan konvektif.

Salah satu kasus turbulensi yang terjadi di wilayah udara Indonesia dialami oleh pesawat komersial rute Jakarta-Medan pada tanggal 24 Oktober 2017 sekitar pukul 09.59 Universal Time
Coordinated (UTC sama dengan UTC+7 untuk waktu lokal). Pada kasus ini disebutkan bahwa pesawat tersebut mengalami CAT (Clear Air Turbulence) pada saat terbang dari Jakarta menuju Kualanamu, Medan (Kompas, 2017). Berdasarkan laporan KNKT (2017) menggunakan data citra satelit dari Badan Meteorologi Klimatologi dan Geofisika terlihat bahwa di lokasi turbulensi tidak terdapat awan kumulonimbus tetapi di sekitar lokasi kejadian terdapat awan konvektif yang relatif besar (Gambar 1a). National Committee for Clear Air Turbulence mendefinisikan CAT sebagai seluruh turbulensi di atmosfer bebas dalam lingkup operasi penerbangan yang tidak berdekatan dengan aktivitas konvektif. Ini termasuk turbulensi yang terjadi di awan cirrus dan tidak dalam atau berdekatan dengan aktivitas konvektif yang 
terlihat (U.S Department of Commerce, 1966; Sharman, 2016).

Kasus yang mirip kejadian ini juga sering dialami oleh pesawat komersial di negara lain dan disebut dengan istilah Near Cloud Turbulence (NCT) (Lane et al., 2012). NCT merupakan fenomena turbulensi yang terjadi di daerah clear air di luar awan dalam jarak horizontal dan vertikal dari batas permukaan awan. Oleh karena itu, pilot yang mengalami NCT umumnya akan melaporkan CAT karena tidak ada awan di area yang dilalui pesawat tersebut. NCT memiliki potensi bahaya yang tinggi karena tidak dapat dideteksi oleh peralatan seperti radar dan citra satelit serta dapat terjadi dalam jarak yang cukup jauh di atas dan di sekitar awan. Proses dinamik yang terjadi dalam kejadian turbulensi di atmosfer dapat diketahui dari indikator seperti Kelvin Helmholtz Instability $(\mathrm{KHI})$, breaking gravity waves, dan Bilangan Richardson (Ri) < 0,25 (Sharman et al., 2012). Parameter Turbulence Kinetic Energy (TKE) juga dapat digunakan untuk mengetahui nilai besaran turbulensi (Stull, 1988). Kemudian untuk mengetahui adanya breaking gravity waves dan $\mathrm{KHI}$ dapat memanfaatkan kontur dari parameter suhu potensial (Trier et al., 2012).

Berdasarkan latar belakang tersebut, maka penulis tertarik untuk mengetahui lebih lanjut tentang fenomena turbulensi yang dialami dalam penerbangan tersebut. Rumusan masalah

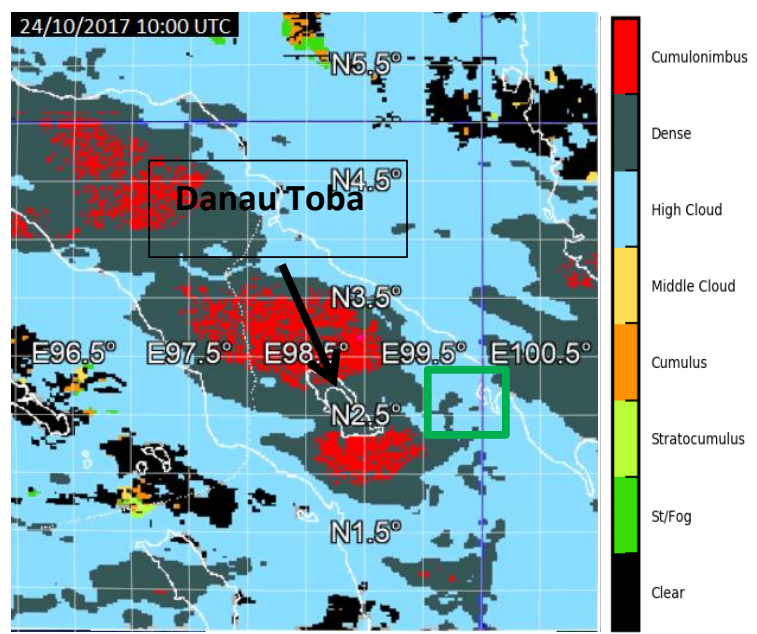

(a) yang akan dibahas adalah bagaimana kondisi atmosfer yang dialami penerbangan tersebut saat mengalami turbulensi dan bagaimana mekanisme penyebab turbulensi pada kasus yang dikaji dalam paper ini dilihat dari parameter-parameter turbulensi. Mekanisme penyebab turbulensi ini akan dibandingkan dengan penelitian Trier dan Sharman (2009), Trier et al. (2012), dan Kim dan Chun (2012) yang membahas tentang NCT.

\section{$1.1 \quad$ Ringkasan kasus turbulensi}

Pada 24 Oktober 2017, (Gambar 1b) pesawat komersial Boeing 737-800 dengan nomor penerbangan ID6890 berangkat dari Bandara Internasional Soekarno-Hatta (Kode International Civil Aviation Organization-ICAO : WIII), Tangerang pada pukul 08.25 UTC dengan tujuan menuju Bandara Internasional Kualanamu (Kode ICAO : WIMM), Deli Serdang. Berdasarkan laporan awal (KNKT, 2017), pesawat lepas landas dari WIII dengan kondisi cuaca cerah dan terbang di ketinggian 36000 kaki (FL360). Pukul 09.42 UTC pesawat berbelok untuk menghindari cuaca buruk. Pada 09.49 UTC pilot mulai turun menuju FL220, dan pada 09.58 UTC pilot menyalakan tanda sabuk pengaman karena mereka melihat potensi turbulensi. Pada 09.59 UTC pesawat mengalami turbulensi kuat yang terjadi selama kurang lebih 20 detik selama fase descent.

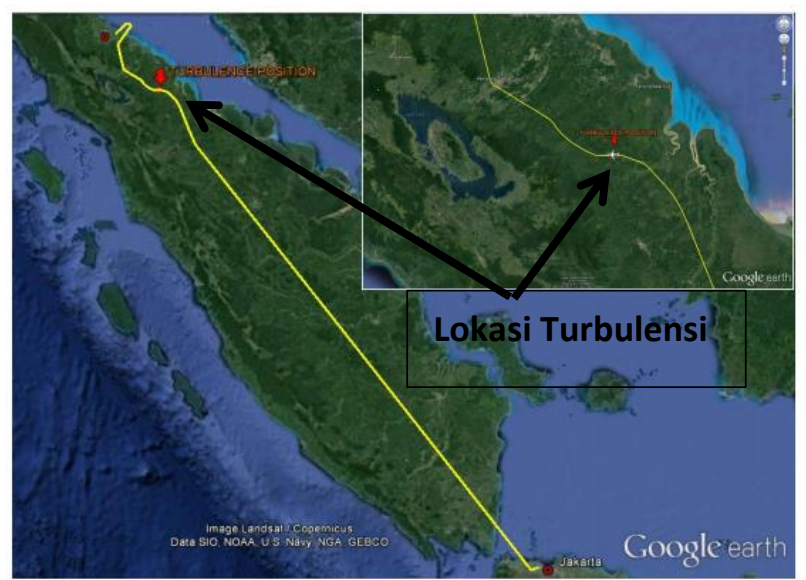

(b)

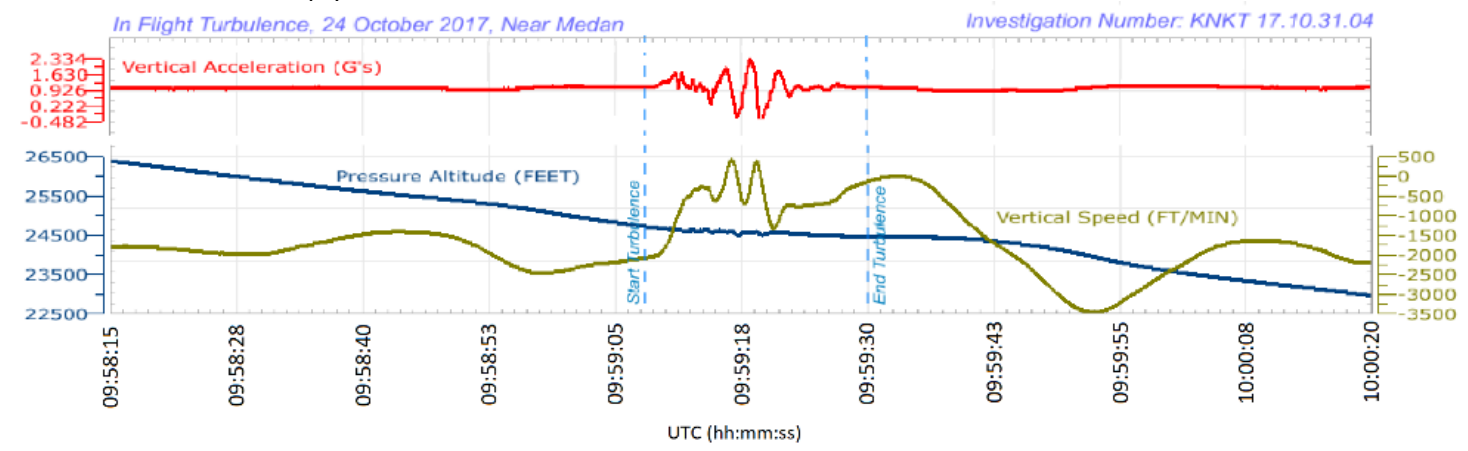

(c)

Gambar 1. a) Citra Satelit Cloud Type 10.00 UTC), b) Jalur pesawat ID6890 24 Oktober 2017, c) Flight Data Recorder pesawat ID6890 24 Oktober 2017 (Sumber: KNKT, 2017) 
Dari grafik Flight Data Recorder pada Gambar 1c, terlihat adanya fluktuasi nilai percepatan vertikal $(\mathrm{g})$ antara $+2,334$ dan $-0,482$ pada ketinggian FL245. Berdasarkan kategori ICAO dalam Molarin (2013), nilai fluktuasi ini mengindikasikan turbulensi yang kuat karena memenuhi kriteria $g \geq 1$. Berdasarkan data citra satelit Himawari menggunakan produk Cloud Type, pada 10.00 UTC (Gambar 1a), terhadap utara dan selatan Danau Toba terdapat awan cumulonimbus tetapi pada lokasi turbulensi (kotak hijau) hanya ditunjukkan keberadaan awan jenis dense dan awan tinggi.

\section{DATA DAN METODE}

\subsection{Data}

Penelitian ini menggunakan simulasi model Advanced Research Weather Research and Forecasting (ARW-WRF) versi 3.9 (Skamarock, 2009). Sebagai initial condition digunakan data dari NCEP GDAS/FNL (National Center for Environmental Prediction Global Data Assimilation System/Final Analysis) yang memiliki resolusi grid horizontal $0,25^{\circ}$ dan resolusi temporal 6 jam. Kemudian, sebagai data banding digunakan data observasi Satelit Himawari kanal IR1 untuk memperoleh suhu puncak awan. Selain itu dimanfaatkan juga data radiosonde Stasiun Meteorologi Kualanamu 24 Oktober 2017 pukul 12.00 UTC untuk mengetahui ketinggian lokasi turbulensi.

\subsection{Metode}

Simuluasi dilakukan pada 3 (tiga) domain: $D 1, D 2$, dan D3 yang merepresentasikan resolusi spasial berturut-turut $9 \mathrm{~km}, 3 \mathrm{~km}$ dan $1 \mathrm{~km}$, seperti ditunjukkan pada Gambar 2 dan Tabel 1. Karena batas atas model memiliki kondisi rigid, maka diterapkan absorption layer dengan tebal $5 \mathrm{~km}$ untuk mencegah pantulan gelombang gravitasi yang merambat vertikal ke bagian atap model. Hal ini juga dilakukan pada Trier et al. (2012) dan Kim dan Chun (2012).

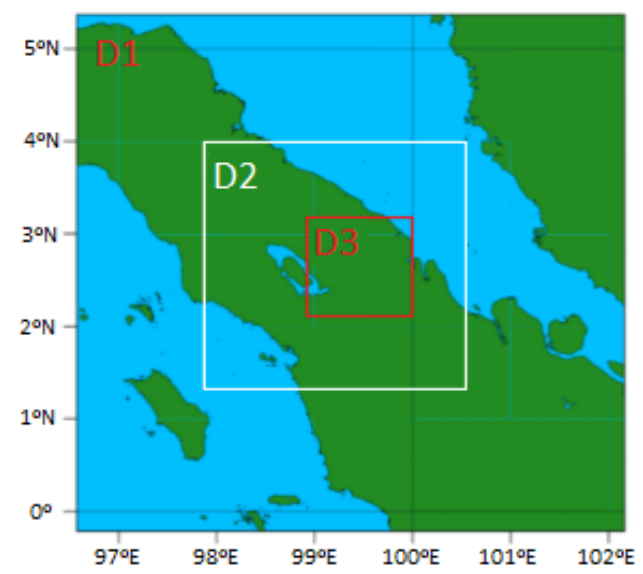

Gambar 2. Area domain penelitian
Simulasi diintegrasikan dengan data sepanjang 36 jam dari 00.00 UTC 23 Oktober hingga 12.00 UTC 24 Oktober 2017. Penelitian ini menggunakan output D2 untuk dibandingkan dengan pengamatan serta untuk mengetahui kondisi lingkungan mesoscale di mana turbulensi terjadi. Kemudian mekanisme turbulensi dan karakteristik awan dibahas menggunakan output D3.

Pemilihan skema mikrofisis WSM-6 berdasarkan Hong et al. (2006) yang menyatakan bahwa skema ini baik untuk model resolusi tinggi. Pemilihan skema MYJ ditujukan agar mendapatkan parameter TKE pada output WRF. Selain itu pemilihan skema berdasarkan kondisi default. Untuk D2 dan D3 skema cumulus tidak diaktifkan karena pada resolusi ini model dapat menyelesaikan perhitungan aktivitas konvektif (Meizhao et al., 2020) dan ini juga karena skema cumulus tidak dapat bekerja dengan baik pada model resolusi tinggi (Arakawa dan Jung, 2011).

Tabel 1. Konfigurasi WRF-ARW

\begin{tabular}{|c|c|c|c|}
\hline \multirow{2}{*}{$\begin{array}{l}\text { Konfigurasi } \\
\text { Model }\end{array}$} & \multicolumn{3}{|c|}{ Domain } \\
\hline & D1 & D2 & D3 \\
\hline $\begin{array}{l}\text { Resolusi } \\
\text { spasial }\end{array}$ & $9 \mathrm{~km}$ & $3 \mathrm{~km}$ & $1 \mathrm{~km}$ \\
\hline $\begin{array}{l}\text { Grid barat- } \\
\text { timur }\end{array}$ & 70 & 100 & 181 \\
\hline $\begin{array}{l}\text { Grid utara- } \\
\text { selatan }\end{array}$ & 70 & 100 & 151 \\
\hline Grid vertikal & \multicolumn{3}{|c|}{82} \\
\hline $\begin{array}{l}\text { Resolusi } \\
\text { temporal }\end{array}$ & $\begin{array}{c}180 \\
\text { menit }\end{array}$ & $\begin{array}{c}30 \\
\text { menit }\end{array}$ & $\begin{array}{c}10 \\
\text { menit }\end{array}$ \\
\hline mikrofisis & \multicolumn{3}{|c|}{ WSM6 } \\
\hline $\begin{array}{l}\text { longwave } \\
\text { radiative }\end{array}$ & \multicolumn{3}{|c|}{ RRTM } \\
\hline $\begin{array}{l}\text { shortwave } \\
\text { radiative }\end{array}$ & \multicolumn{3}{|c|}{ Goddard } \\
\hline PBL & \multicolumn{3}{|c|}{ MYJ } \\
\hline cumulus & $\begin{array}{l}\text { Kain- } \\
\text { Fritsch }\end{array}$ & - & - \\
\hline
\end{tabular}

\section{HASIL DAN PEMBAHASAN}

\subsection{Perbandingan Simulasi Dengan Observasi}

Untuk menguji kemampuan WRF-ARW dalam menyimulasikan kasus turbulensi, perlu dilakukan verifikasi dengan data observasi yang merepresentasikan kondisi aktual. Semakin mirip hasil model dengan observasi, maka dapat dianggap kemampuan model akan semakin mendekati kondisi sebenarnya (Trier et al., 2012). Perbandingan dilakukan dengan membandingkan parameter suhu puncak awan (SPA) dari WRF-ARW dan citra IR1 Himawari sebagai data observasi. Pada Gambar 3, SPA ditampilkan pada 10.00 UTC (saat kejadian) dan 10.30 UTC (setelah kejadian). Diantara waktu tersebut terjadi perubahan kondisi awan yang signifikan di lokasi turbulensi (tanda bintang pada 
Gambar 3a dan 3c.). Pada Gambar 3c terdapat dua ukuran besar sistem konvektif dalam (sekitar $1^{\circ} \times 1^{\circ}$ ) yang terletak di utara Danau Toba (selanjutnya disebut SK1) dan di selatan Danau Toba (selanjutnya disebut SK2) dengan SPA terendah mencapai kurang dari $-70{ }^{\circ} \mathrm{C}$ yang menunjukkan awan kumulonimbus berdasarkan Gambar 1a. Tampak kemunculan awan konvektif baru yang mulai muncul pada pukul 10.30 UTC dengan SPA $\leq 70{ }^{\circ} \mathrm{C}$ di lokasi turbulensi (tanda bintang pada Gambar 3a dan 3c). Berdasarkan hal tersebut maka perhatian akan difokuskan pada lokasi kejadian.

Berbagai proses yang terjadi pada observasi awan di citra IR1 akan dijadikan acuan untuk memverifikasi hasil simulasi model WRF-ARW. Dapat dilihat dari hasil simulasi WRF-ARW pada Gambar 3b dan 3d. Pada 10.00 UTC (Gambar 3b) menunjukkan sistem konvektif di sebelah utara Danau Toba (SK1) yang memiliki tampilan hampir mirip seperti observasi IR1. Kemiripan SK1 antara citra satelit dan WRF-ARW terletak pada adanya area

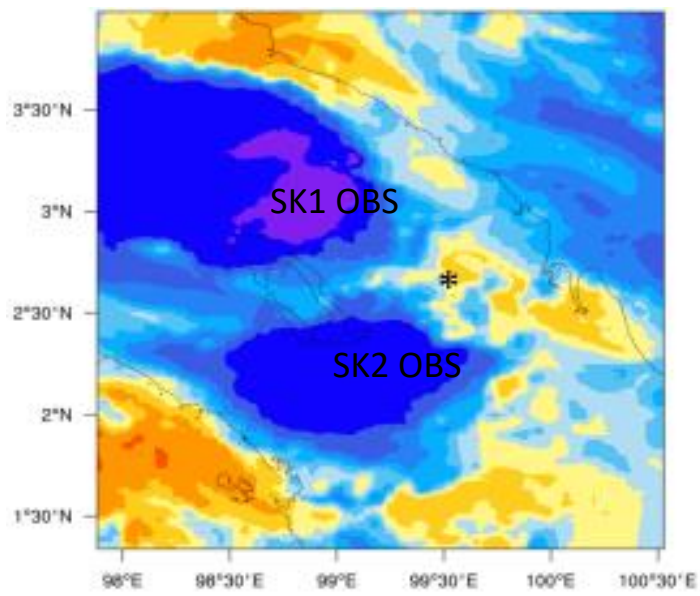

(a)

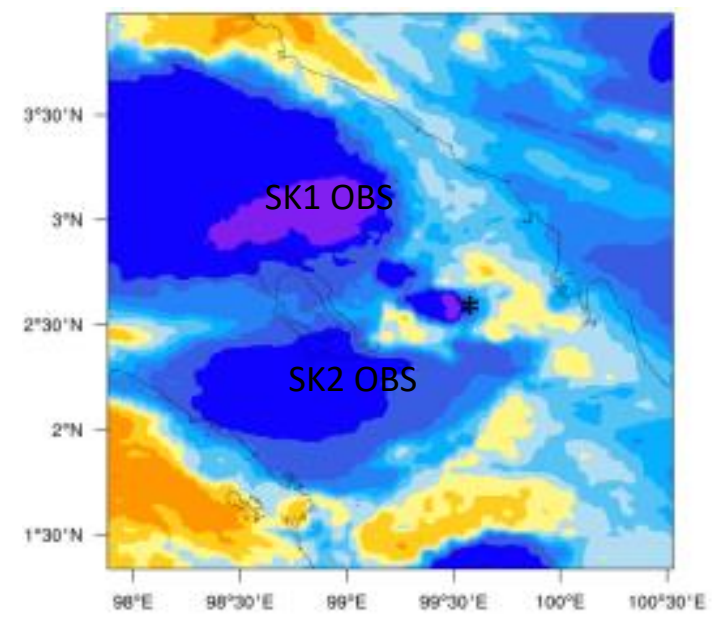

(c)
SPA $\leq 70^{\circ} \mathrm{C}$ di bagian depan (sisi bagian timur) SK1. Meskipun mirip, posisi SK1 WRF-ARW cenderung bergeser sedikit ke barat dibandingkan pengamatan citra satelit (Gambar 3a). WRF-ARW juga berhasil menyimulasikan sistem konveksi di selatan Danau Toba (SK2) seperti yang ditemukan pada citra satelit. Namun kondisi tersebut cukup berbeda dengan pengamatan dimana area SPA $\leq-60{ }^{\circ} \mathrm{C}$ hasil WRF memiliki cakupan yang lebih luas dibandingkan dengan observasi. Kemudian SPA $\leq-70^{\circ} \mathrm{C}$ untuk SK2 cenderung bergeser sedikit ke arah timur dibandingkan dengan data citra satelit.

Berdasarkan hasil perbandingan hasil simulasi model dan data observasi, terdapat bias spasial yang dihasilkan model. Hal ini dapat dipengaruhi oleh kondisi lokal yang cukup kuat (Bugichi et al., 2019). Oleh karena itu, lokasi turbulensi juga tidak akan berada dititik atau lokasi yang sama dengan observasi. Tetapi secara umum pembentukan SK1 dan SK2 di model cukup menunjukkan performa yang

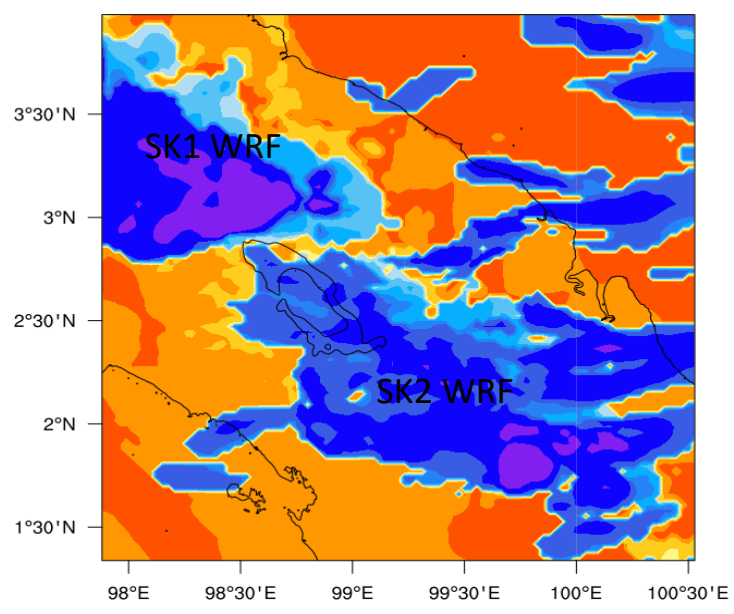

(b)

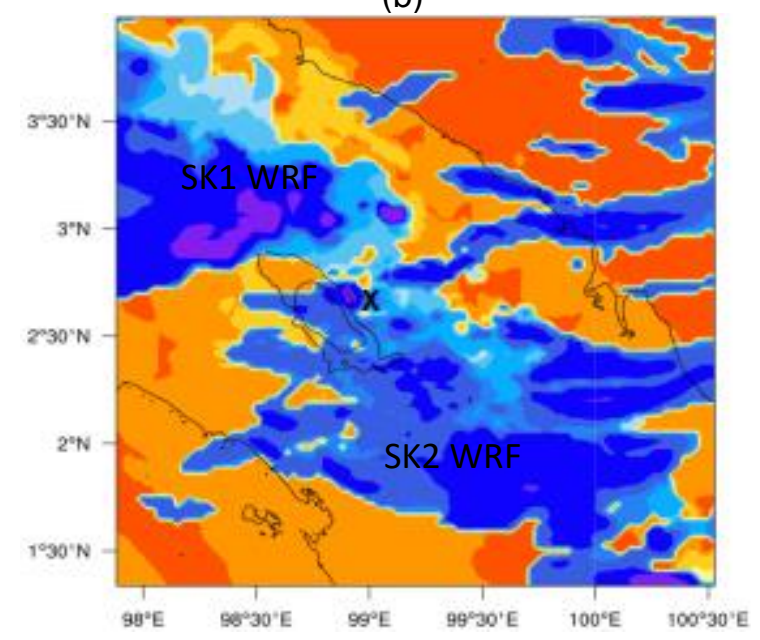

(d)

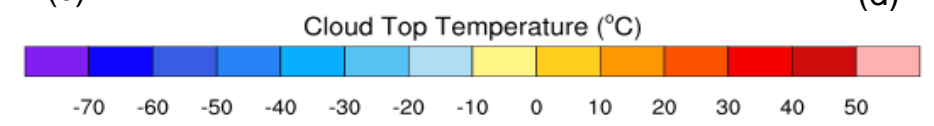

Gambar 3. Suhu Puncak Awan, perbandingan antara observasi dan simulasi WRF-ARW. a) observasi 10.00 UTC, b. WRF-ARW 10.00 UTC, c. observasi 10.30 UTC, d. WRF-ARW 10.30 UTC. Tanda bintang mengindikasikan lokasi nyata kejadian turbulensi, dan tanda silang dipilih sebagai lokasi turbulensi dalam simulasi WRF-ARW. 
isentropik bergelombang masih terbentuk di atas puncak awan pada ketinggian yang sama dan tidak mengalami perubahan yang signifikan dengan kondisi sebelumnya. Pada 10.00 UTC (Gambar 5d) yang merupakan waktu turbulensi yang dialami oleh pesawat, ketinggian puncak awan kembali turun sedikit menjadi 9,2 km dan juga diikuti dengan penurunan updraft menjadi $4 \mathrm{knot}$ pada $z=9 \mathrm{~km}$.

Kontur isentropik pada saat itu masih menunjukkan pola bergelombang tepat di tanda bintang sehingga berpotensi berkontribusi pada turbulensi. Selain itu perlu diperhatikan juga bahwa pada $y=15-25 \mathrm{~km}$ (Gambar $5 d$ ) terdapat sel konvektif baru dengan ketinggian puncak awan mencapai $7 \mathrm{~km}$ namun memiliki updraft yang cenderung kuat hingga 10 knot. Dimana sebelumnya pada Gambar $5 a$ dan b sel konvektif baru ini belum terlihat jelas. Berdasarkan analisis tersebut dapat diketahui bahwa pada lokasi turbulensi, awan telah berkembang sebelum pukul 09.30 UTC dan semakin kuat hingga pukul 09.40 UTC dan membentuk kontur isentropik bergelombang pada ketinggian 9,5 km tepat di lokasi tersebut. Kondisi awan terlihat melemah pada pukul 09.50 dan 10.00 UTC namun kondisi isentropik yang

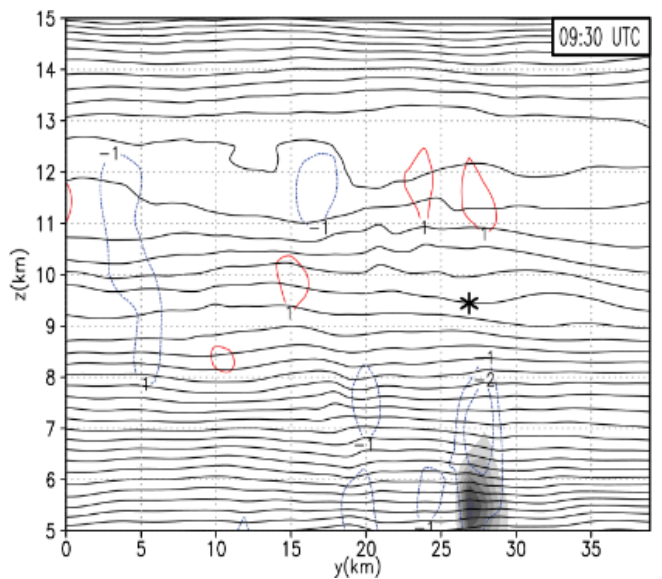

(a)

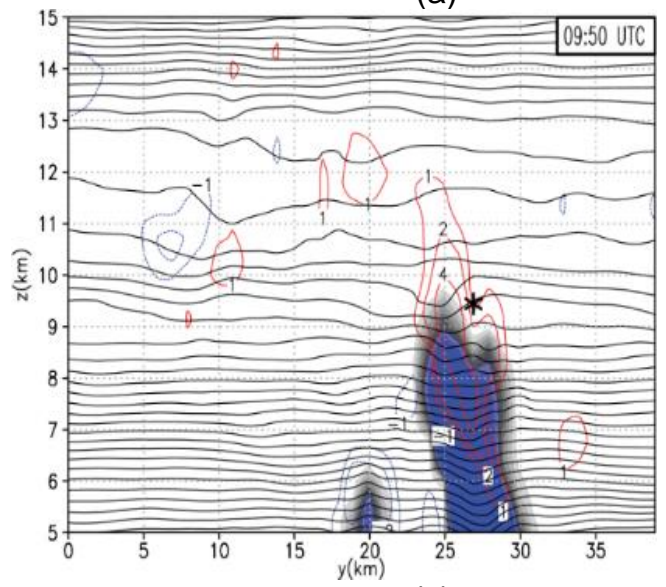

(c) bergelombang masih terjadi pada saat itu. Kemudian pada 10.00 UTC sel konvektif baru tumbuh di bawah lokasi turbulensi dengan kondisi yang semakin kuat di waktu berikutnya. Berdasarkan Gambar 5 terlihat bahwa turbulensi yang dialami oleh pesawat lebih disebabkan oleh sistem konvektif di bawah lokasi turbulensi yang sedang melemah ditandai oleh tinggi puncak awan yang menurun tetapi masih menyisakan pola isentropik bergelombang dilokasi kejadian. Sedangkan awan yang semakin kuat yang terdeteksi pada pukul 10.30 UTC merupakan konvektif baru yang tumbuh di sebelah lokasi kejadian tetapi tidak memiliki pengaruh langsung terhadap kondisi turbulensi di lokasi kejadian.

Gambar 6 menunjukkan nilai Bilangan Richardson $(R I)$ dan TKE di sekitar tanda bintang pada $z=9,5 \mathrm{~km}$. Ri dihitung berdasarkan Persamaan 1. TKE dihitung melalui penjumlahkan antara TKE skala sub grid yang dihasilkan skema MYJ PBL (Trier et al., 2012; Kim dan Chun, 2012) dengan TKE dari Persamaan 2 dan disebut dengan total TKE (Kim dan Chun, 2012). TKE Persamaan 2 di sini menggunakan moving average setiap komponen kecepatan pada $10 \times 10$ titik grid.

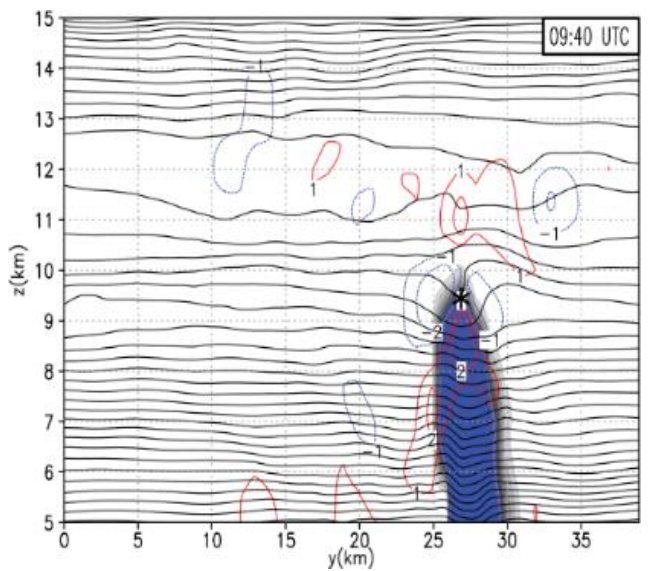

(b)

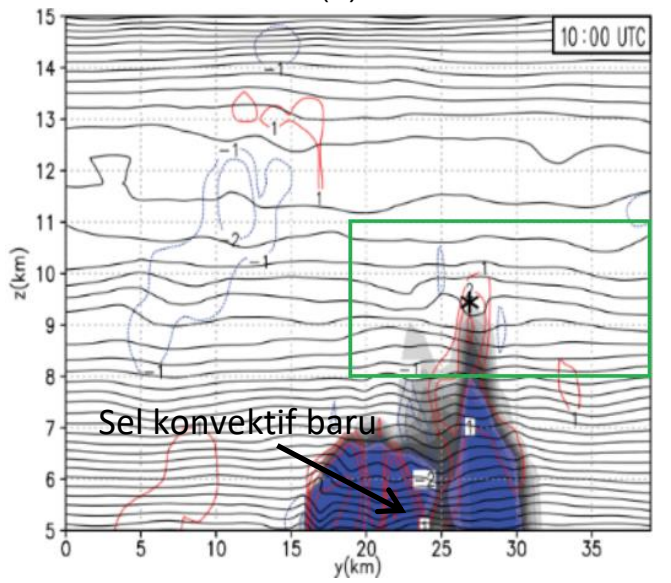

(d)

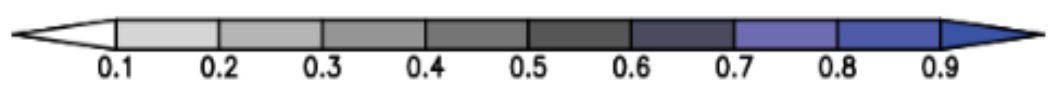

Gambar 5. Penampang vertikal (garis A-B Gambar 4). Kontur warna menunjukkan total condensate cloud $(\mathrm{g} / \mathrm{kg})$, kontur hitam menunjukkan isentropik interval $0.5 \mathrm{~K}$, kontur biru/merah menujukkan downdraftlupdraft, dan tanda bintang menunjukkan lokasi turbulensi. a. 09.30 UTC, b. 09.40 UTC, c. 09.50 UTC, and d. 10.00 UTC (kotak hijau sebagai referansi Gambar 6). 


$$
R i=\frac{\frac{g}{\theta} \frac{\Delta \theta}{\Delta z}}{\left(\frac{\Delta u}{\Delta z}\right)^{2}+\left(\frac{\Delta v}{\Delta z}\right)^{2}}
$$

dengan $R i$ menunjukkan bilangan Richardson, $g$ menotasikan percepatan gravitasi $\left(\mathrm{m} / \mathrm{s}^{2}\right), \theta$ merupakan suhu potensial $(\mathrm{K}), z$ menotasikan ketinggian geopotensial $(\mathrm{m})$ dan $u, v$ menotasikan angin zonal dan meridional $(\mathrm{m} / \mathrm{s})$.

$e=\frac{1}{2}\left(\overline{u^{\prime 2}}+\overline{v^{\prime 2}}+\overline{w^{\prime 2}}\right)$

dengan $e$ adalah TKE per satuan massa $\left(\mathrm{m}^{2} / \mathrm{s}^{2}\right)$, $u^{\prime}$ adalah deviasi angin zonal terhadap rata-ratanya $(\mathrm{m} / \mathrm{s}), v^{\prime}$ adalah deviasi angin meridional terhadap rata-ratanya $(\mathrm{m} / \mathrm{s})$, dan $w^{\prime}$ adalah deviasi angin vertikal terhadap rata-ratanya $(\mathrm{m} / \mathrm{s})$.

Pada 10.00 UTC potensi turbulensi terlihat di lokasi turbulensi yang ditandai dengan adanya nilai $R i$ kritis $(R i \leq 0,25)$ di tanda bintang. Hal ini juga terbukti bahwa terdapat pola bergelombang dari kontur isentropik yang berada tepat di lokasi turbulensi, serta menunjukkan sebaran nilai TKE di lokasi turbulensi dengan nilai maksimum $4,4 \mathrm{~m}^{2} / \mathrm{s}^{2}$.

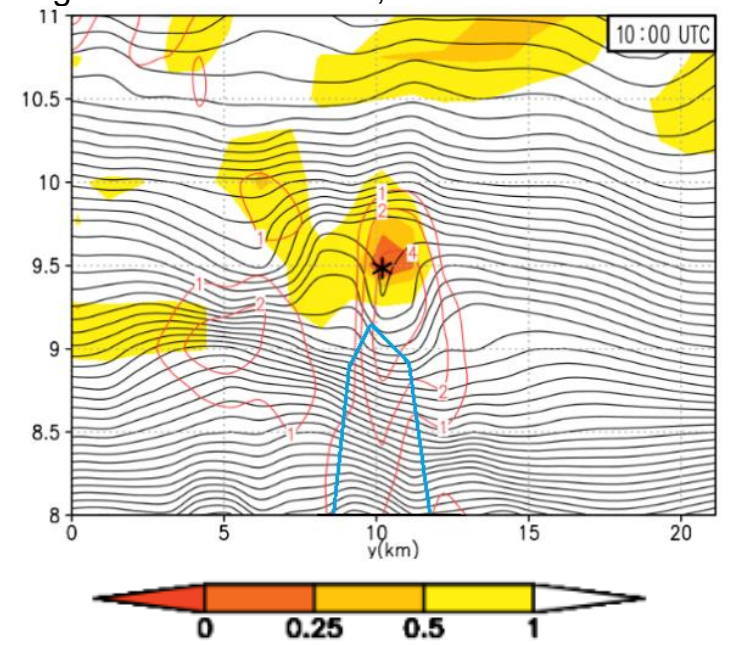

Gambar 6. Bilangan Richardson (berwarna), TKE (kontur merah) isentropic interval $0,2 \mathrm{~K}$ (kontur hitam), dan batas awan (garis biru $=0,1 \mathrm{~g} / \mathrm{kg}$ total cloud condensate) jam 10.00 UTC. Tanda bintang menunjukkan lokasi turbulensi.

\subsection{Analisis Mekanisme Turbulensi}

Dari hasil analisis model WRF-ARW, di utara dan selatan lokasi turbulensi telah terjadi sistem konvektif yang tumbuh dalam skala yang relatif besar (melebihi $1^{\circ} \times 1^{\circ}$ ). Kedua sistem konvektif ini berperan dalam mempengaruhi kondisi atmosfer dari ketinggian permukaan hingga ketinggian 9,5 km.
Tetapi sistem konvektif yang mempengaruhi lokasi turbulensi hanya sistem konvektif di utara (SK1). Pada ketinggian 9,5 km, arus keluar dari SK1 cenderung bertiup ke selatan dengan kecepatan berkisar 10-20 knot. Beranjak dari pengaruh SK1 di lokasi kejadian, tepat di lokasi tersebut juga terdapat sistem konvektif yang lebih kecil yang juga menjadi faktor utama terbentuknya turbulensi di lokasi turbulensi.

Kondisi awan di lokasi turbulensi mencapai ketinggian maksimum pada 09.40 UTC dan berhasil mengubah kontur isentropik pada ketinggian $9,5 \mathrm{~km}$. Pola isentropik yang patah/bergelombang (overturning isentopic) ini tetap ada di sekitar ketinggian 9,5 - 9,9 km pada 09.50 dan 10.00 UTC meskipun batas ketinggian puncak awan telah berkurang menjadi 9,2 km. Pada Gambar 6, overturning isentropic jika dilihat lebih detail, telah membentuk gelombang gravitasi pecah (breaking gravity wave) yang memberikan potensi turbulensi yang kuat pada ketinggian sekitar $300-700 \mathrm{~m}$ di atas awan.

Terbentuknya overturning isentropic di ketinggian 9,25-9,75 km berkontribusi terhadap nilai Ri kritis yang mengindikasikan dukungan terjadinya turbulensi di atmosfer pada ketinggian $9,5 \mathrm{~km}$ (Gambar 7a). Kondisi ini disebabkan karena gradien temperatur potensial terhadap ketinggian mengalami penurunan terhadap ketinggian sehingga menyebabkan nilai buoyancy yang rendah bahkan negatif pada level 9,5 km (Gambar 7b). Berdasarkan kontur isentropik (Gambar 6), pola kontur temperatur yang hampir memiliki pola sejajar sumbu vertikal dapat menjadi indikasi pecahnya gelombang gravitasi (breaking gravity wave) pada ketinggian 9.25-9.75 $\mathrm{km}$. Isentropik bergelombang yang menjadi breaking gravity wave ini disebabkan oleh pendinginan karena arus atas yang dihasilkan oleh awan (Kim dan Chun, 2012). Kondisi ini tampaknya berlangsung lebih lama dibandingkan dengan keberadaan puncak awan di lokasi turbulensi yang sudah turun. Ini mengakibatkan di lokasi turbulensi tidak terdapat awan namun breaking gravity wave dan Ri kritis masih tetap ada. Dua parameter yang berkontribusi pada pembentukan nilai Ri rendah adalah stabilitas statis rendah dan shear yang besar (Duran dan Molinari, 2016). Parameter ini dapat memperkuat dan melemahkan satu sama lain yang mempengaruhi nilai Ri. Pada kasus turbulensi ini (Gambar $7 b$ ) nilai stabilitas statik pada ketinggian $9,5 \mathrm{~km}$ sangat rendah $\left(-0,496 \times 10^{-5} \mathrm{~s}^{-2}\right.$, nilai negatif menunjukkan telah mencapai kategori instabilitas statik), disertai dengan nilai shear kuadrat yang relatif besar $\left(6.253 \times 10^{-5} \mathrm{~s}^{-2}\right)$ pada ketinggian $9,5 \mathrm{~km}$ (Gambar 7c). Oleh karena itu, dapat dilihat bahwa kedua parameter ini memberikan efek yang saling menguatkan pada pembentukan $R i$ kritis di ketinggian $9,5 \mathrm{~km}$. Jika dibandingkan dengan nilai $\mathrm{Ri}$ saat tidak ada aktivitas konvektif, pada ketinggian $9,5 \mathrm{~km}$ menunjukkan nilai apung yang tinggi dengan geser yang relatif lemah sehingga menghasilkan nilai $R i$ yang besar. 


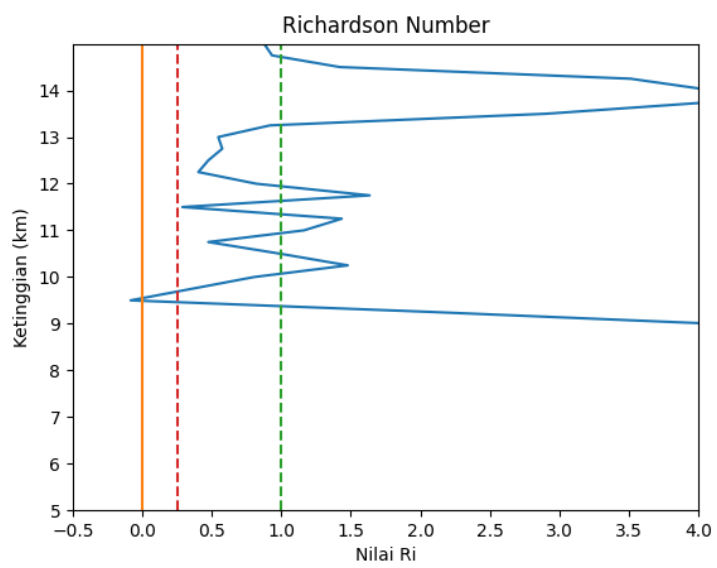

(a)

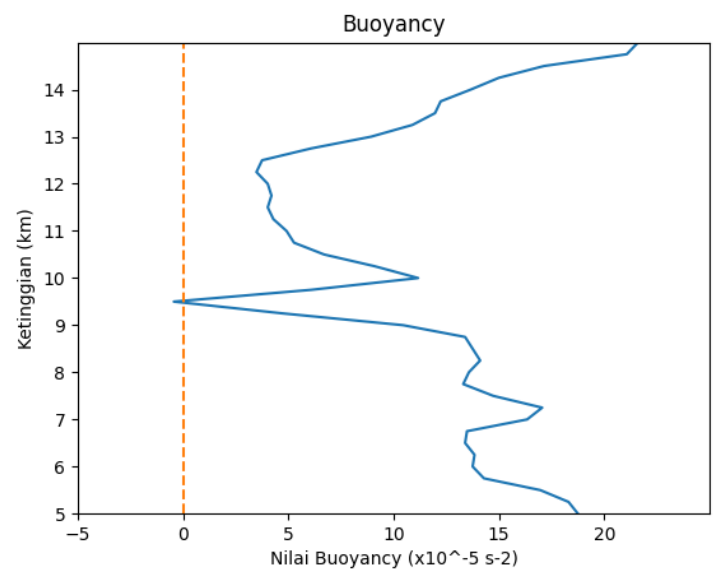

(b)

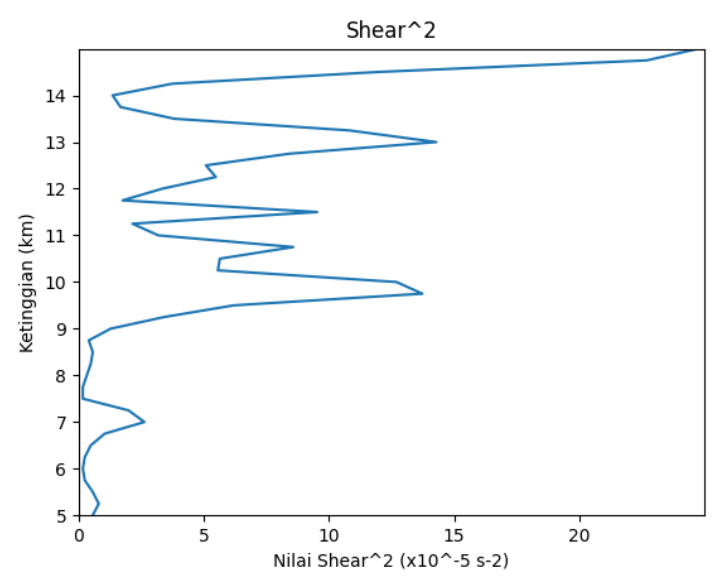

(c)

Gambar 7. Profil vertikal (a) Richardson Number - garis jingga $\mathrm{Ri}=0$, garis putus-putus merah $\mathrm{Ri}=0,25$ (batas Ri kritis) dan garis putus-putus hijau $\mathrm{Ri}=1,0$, (b) Buoyancy (stabilitas statis) - garis jingga Buoyancy $=0$, dan (c) Shear^2 di lokasi turbulensi

Penyebab kestabilan statik yang rendah disebabkan oleh breaking gravity wave dan terjadi shear yang relatif besar akibat dari angin sistem konvektif di arah utara lokasi turbulensi. Kedua fenomena tersebut berkontribusi pada nilai $R i$ kritis di lokasi turbulensi. Hal ini mirip dengan penelitian Trier dan Sharman (2009) dimana adanya peran angin yang dihasilkan oleh sistem konvektif sehingga membentuk wind shear vertikal sehingga berkontribusi menurunkan nilai $R i$.

\section{KESIMPULAN}

Berdasarkan analisis dan pembahasan secara keseluruhan, turbulensi di dekat awan konvektif yang dialami oleh penerbangan komersial ID6890 pada tanggal 24 Oktober 2017 berdasarkan simulasi model WRF-ARW terjadi di sekitar 300-700 meter di atas puncak awan. Ada dua faktor yang berkontribusi terhadap turbulensi ini, yang pertama adalah pendinginan atmosfer akibat updraft dari sistem konvektif yang melemah yang masih bertahan di lokasi turbulensi sehingga membentuk breaking gravity wave dan yang kedua adalah sistem konvektif di utara lokasi turbulensi berkontribusi kepada pembentukan shear vertikal pada ketinggian $9,5 \mathrm{~km}$. Keduanya memberikan efek yang saling menguatkan saat turbulensi terjadi di ketinggian $9,5 \mathrm{~km}$ yang diindikasikan dari nilai bilangan richardson rendah yang terbentuk dilokasi kejadian. Selain itu nilai TKE sebesar $4,4 \mathrm{~m}^{2} / \mathrm{s}^{2}$ juga membantu meningkatkan daya turbulensi di lokasi tersebut.

\section{DAFTAR PUSTAKA}

Arakawa, dan Jung, J.-H., (2011). Multiscale modeling of the moist convective atmosphere. A review. Atmos. Res. 102. 263-285.

doi: 10.1175/AMSMONOGRAPHS-D-150014.1

Duran, P. dan Molinari, J. (2016). Uppertropospheric low richardson number in tropical cyclones: sensitivity to cyclone Intensity and the diurnal cycle. J. Atmos. Sci, 73, 545-54. doi: 10.1175/JAS-D-150118.1

Hong, S-Y., Kim, J-H., Lim, J., dan Dudhia, J., (2006). The WRF single moment microphysics scheme (WSM). Journal of 
the Korean Meteorological Society. 42. 129151.

Kim, J. H., dan Chun, H. Y., (2012). A numerical simulation of convectively induced turbulence above deep convection. J. Appl. Meteor. Climatol, 51, 1180-1200. doi: 10.1175/JAMC-D-11-0140.1

KNKT. (2017) Aircraft accident investigation report PT. Batik Air Boeing 737-800; PK-LBY inflight from Jakarta to Medan Republic of Indonesia 24 October 2017 Preliminary: NTSC.17.10.31.04. Indonesia: National Transportation Safety Committee Republic of Indonesia

Kompas, (2017). Batik Air Alami Turbulensi, Satu Penumpang dan Awak Alami Patah Tulang Tanggal 25 Oktober 2017 Pukul 15.29 WIB. (https://regional.kompas.com/read/20 17/10/25/15293911/batik-air-alamiturbulensi-satu-penumpang-dan-awakalami-patah-tulang.)

Lane, T. P., Sharman, R. D., Clark, T. L. dan Hsu, H. M., (2003). An Investigation of turbulence generation mechanisms above deep convection. J. Atmos. Sci., 60, 12971321. doi: 10.1175/15200469(2003)60<1297:AIOTGM>2.0.CO;2

Lane, T. P., Sharman, R. D., Trier, S. B., Fovell, R. G. dan William, J. K., (2012). Recent advances in the understanding of nearcloud turbulence, Bull. .Amer. Meteor. Soc.
93, 499-515. doi:10.1175/BAMS-D-1100062.1

Molarin, K., (2013). Case study of CAT over the North Atlantic Ocean. Stockholm: University Stockholm

Sharman, R. D., dan Lane, T. P. (2016). Aviation turbulence: process, detection, prediction. Colorado: Springer Inc.

Skamarock, W. C., Klemp, J. P., Dudhia, J., Gill, D. O., Barke, D. M, Duda, M. G., Huang, X. Y., Wang, W., dan Powers, J. G., (2008). A description of the advanced research WRF version 3. Colorado: National Center for Atmospheric Research (NCAR)

Trier, S. B., Sharman, R. D., dan Lane, T. P., (2012). Influence of moist convection on a cold-season outbreak of clear-air turbulence (CAT). Mon. Wea. Rev., 140, 2477-96. doi: 10.1175/MWR-D-11-00353.1

Trier, S. B. dan Sharman, R. D., (2009). Convective-Permitting Simulations of The Environment Supporting Widespread Turbulence Within The Upper-Level Outflow of A Mesoscale System, Mon. Wea. Rev., 137, 1972-1990. doi: 10.1175/2008MWR2770.1

Storer, L.N., Williams, P.D. dan Gill, P.G., (2012) Aviation Turbulence: Dynamics, Forecasting, and Response to Climate Change. Pure Appl. Geophys. 176, 20812095. doi: 10.1007/s00024-018-1822-0 